\title{
САМОТВОРЧЕСТВО КАК ПРОТЕСТНЫЙ ПОТЕНЦИАЛ ДУХОВНОЙ КУЛЬТУРЫ
}

\author{
А. А. Горелов \\ Институт философии РАН, \\ Т. А. Горелова \\ Московский гуманитарный университет
}

Аннотация: В работе представлены контуры определения философского статуса понятия «самотворчество», понимаемого как особая разновидность творчества, относящегося к самому твориу, который пытается изменить себя в соответствии со своими представлениями об идеале.

Ключевые слова: самотворчество; духовная практика; исихазм; творчество; истина; смысл; личность; М. Фуко

\section{SELF-CREATION AS THE PROTEST POTENTIAL OF SPIRITUAL CULTURE}

\author{
A. A. Gorelov \\ RAS Institute of Philosophy, \\ T. A. Gorelova \\ Moscow University for the Humanities
}

Abstract: The paper presents the contours of the definition given to the philosophical status of the concept "self-creation», which is understood as a special kind of creativity relating to the creator themself, who is trying to change themself in accordance with their understanding of the ideal.

Keywords: self-creation; spiritualpractice; hesychasm; creativity; truth; sense; personality; M. Foucault

\section{Введение}

В данной работе сделана попытка определения философского статуса понятия «самотворчество» и его значения в современном социуме. Мы понимаем самотворчество (далее - CT) как особую разновидность творчества, относящегося к самому творцу, который пытается изменить себя в соответствии со своими представлениями об идеале. Словосочетания «самотворчество» и «творчество себя», вероятно, впервые встречаются в работах русских религиозных философов Н. А. Бердяева, В. С. Соловьева, С. Л. Франка. В англоязычной литературе аналогичного словосочетания self-creation нет в современной энциклопедии творчества (Encyclopedia of Creativity, 1999). На наш взгляд, наиболее точно внутренний «дух» СТ «ухватил» А. Белый, 
который рассматривал творчество как разыгрывающуюся драму: «Первый акт творчества есть создание мира искусств; акт второй: созидание себя по образу и подобию мира; но мир созданных форм не пускает творца в им созданное царство свободы; у порога его стоит страж: наше косное «я»; борьба с собственной бренною формой, со стражем порога, и есть встреча с роком, трагедия творчества <...> Акт третий: вступление в царство свободы и новая связь безусловно свободных людей для создания общины жизни по образу и подобию новых имен, в нас таинственно вписанных духом» (Белый, 1990: 485; далее везде, где нет указаний, курсив источника. - А. Г., Т. Г.). СТ выступает у теоретика русского символизма как закономерная составляющая духовной жизни - одновременно и отдельного человека, и всей культуры в целом. Таким образом, СТ, как и творчество, самосознание, смыслополагание, формирование системы ценностей можно отнести к высшей способности человека - духовности.

Диапазон определений духа и духовности как способности человека к особому мироощущению необычайно широк. В предлагаемом здесь подходе к определению этого понятия мы исходим из концепции структурных уровней организации бытия, на основании которой дух обладает свойством иерархичности: 1) относительно автономен от материальных уровней; 2) возвышается над ними; 3) призван руководить ими (Горелов, 2013а: 28). Хотя духовное движение имеет явно не «горизонтальный», а «вертикальный» характер, оно создает широкую сферу духа, в которой «сознание мира, самосознание и сознание бога образуют неразрывное структурное единство» (Шелер, 1988: 90). Дух возвышается над соматическими и психическими характеристиками, объединяя их в триединство тела, души и духа. И в то же время он образует верхний, эволюционно самый высокий уровень человека, соотносящийся с надчеловеческими уровнями организации мира и призывающий человека «постигнуть формальную идею надмирного, бесконечного и абсолютного бытия» (там же: 89). Современное определение духа предполагает, что, помимо интеллекта, сознания, идеалов и ценностей, в его сферу входит и духовное бессознательное.

Изменения начала XX в. привели к тому, что осознание развития духа в русской культуре происходило через понятия «очистительный огонь» (А. И. Герцен, А. Блок) «взрыв» и «революция» (А. Белый, В. Маяковский, Н. А. Бердяев). А. Белый в работе «Революция и культура» (1917) оформляет концепцию революции духа: «Прометеев духовный огонь есть очаг революции в предреволюционное время <...> Революция начинается в духе <...> В революции экономических и правовых отношений мы видим последствия революционно-духовной волны; в пламенном энтузиазме она начинается; ее окончание - опять-таки в духе...» (цит. по: Петров, 2018: 78). Усиливая 
Научные труды Московского гуманитарного университета 2019 № 1

мысль А. Белого, что рождение новой духовности всегда революция, которую не следует смешивать с революциями политическими и социальными, Н. А Бердяев пишет, что «... револющия духа родится от глубокой внутренней реакции против ваших революций, против вашего отрицания всякого духа» (Бердяев, 1923: 13). Еще одной отличительной чертой духовной революции является тот факт, что она совершается не массами, как социальные революции, а одиночками, малым числом гениев, сотворивших сначала себя, а затем совершивших духовный переворот вокруг себя, повернув тем самым колесо истории. Иными словами, СТ по своей природе является творческим революционным актом протеста против энтропии обыденности.

Для определения границ понятия «самотворчество» следует провести разграничение с другими понятиями, с одной стороны, более широкими «творчество», с другой, близкими по смыслу - «самосовершенствование», «практика себя», «самоактуализация».

\section{Самотворчество и творчество}

Под творчеством в широком смысле мы понимаем создание качественно нового, причем созданные «изделия» остаются, запечатлеваются в культуре. Само понятие включает две стороны: это процесс, а не состояние; в нем существует некий переход от старого к новому - как отражение акта божественного творения мира, который стал «абсолютной новизной» (Бердяев, 1993: 117), а Бог - Творцом. «Творчество в мире потому только и возможно, что мир сотворен, что есть Творец. И человек, сотворенный Творцом и по его образу и подобию, есть также творец и призван к творчеству» (там же). Творчество служит «высвобождению скрытого» (Г. Марсель) не только в мире, но и в самом человеке. Творческий акт предполагает «выхождение за пределы себя самого, «переливание через край», возникновение доселе не бывшего» (Франк, 1990: 247), рождение определенности из неопределенного. Состояние личности, осуществляющей «высвобождение скрытого», «выхождение за пределы себя» несет особый потенциал, открывающий нечто, до того скрытое в самом человеке, - его духовную потенцию, «так как в самой природе... «художник» или «творец»... находится сам внутри формируемого им материала» (там же: 248). Такое понимание творчества — «во всех областях, в которых оно может вообще иметь место, - означает прорыв в нашем непосредственном самобытии, в нашей субъективной жизни» (там же: 399), т. е. имеет аспект СТ.

Способность человека к творчеству проявляется, с одной стороны, как отзвук его происхождения из природы, а, с другой стороны, как результат «образа и подобия Богу», поэтому творчество, а значит, и СТ, должны иметь онтологическую (свойство природы), гносеологическую (способность со- 
знания), антропологическую и социальную составляющие. Онтологическую основу СТ составляет внутренняя работа по самоосуществлению. Согласно M. Хайдеггеру, это означает обнаружение в себе Dasein, сущего, «которое среди прочего обладает бытийной возможностью спрашивания», одновременно являясь «способом понимания бытия» (Хайдеггер, 1997: 7). Гносеологическая способность кроется в возможности самопознания, открывания новизны в самом себе. Отказ от das Man во имя Dasein в антропологическом смысле означает уход от массовидности к Личности. Социальная составляющая требует выхода из системы «потребления ради потребления» на всех уровнях - экономическом, политическом, экологическом и т. п. В СТ заложен призыв так изменить себя, чтобы вслед за этим изменился Другой, социум, и, в конце концов, направление исторического процесса.

Одна из версий творчества как тотальной особенности мира представлена в концепции творческой эволюции А. Бергсона. По Бергсону, «самопроизвольность жизни выражается в непрерывном творчестве форм, следующих друг за другом» (Бергсон, 2001: 110). Как позже становится ясно, формообразование может идти линейно (дарвинизм), как последовательность «жизненный порыв - кристаллизация» (А. Бергсон), как переход из неравновесности к диссипативной структуре (синергетика) или с помощью другого, неизвестного сейчас механизма, но высшим результатом творческой потребности природы становится рождение сознания.

По своему происхождению сознание не может не обладать творческим компонентом, более того потребность непрерывного творчества происходит из самого акта сознания: потребности его совпадения «с чем-то из своего первоначала... чтобы оно отделилось от ставшего и присоединилось к становящемуся» (там же: 235). Гносеологической основой творчества является, по Бергсону, диалектика интуиции и интеллекта как «двух противоположных направлений сознательного труда» (там же: 259): интуиция осуществляет творческий порыв, а интеллект идет в обратном направлении: он «должен видеть себя в форме прерывности», «всегда стремится воссоздавать... из данного», но при этом он «упускает то, что является новым в каждый момент истории... Он отбрасывает всякое творчество» (там же: $171,174)$. Происхождение интеллекта в ряду эволюционного усложнения нервной системы животных связано с моментом появления существа, которое обладает «способностью фабриковать искусственные предметы, в частности орудия для создания орудия, и бесконечно разнообразить их изготовление» (там же: 153), т. е. интеллект хоть и наивысшее, но рутинное приспособление к повседневной жизни. «...Чтобы покорить материю и вновь овладеть самим собой, сознанию пришлось истощить лучшие свои силы» (там же: 260) и стать... интеллектом. Но интуиция как способность к 
Научные труды Московского гуманитарного университета 2019 № 1

творчеству «все же существует, хотя в неотчетливой и прерывистой форме» (там же). Неравновесность интеллекта и интуиции создает одновременно и напряжение, и субъективность творчества отдельного человека. Отсюда несовпадение творческой способности как онтологического свойства природы и как гносеологической возможности сознания: творчество природы спонтанно, стихийно, непрерывно, объективно, тогда как сознание «проявляется только там, где творчество возможно. Оно засыпает, если жизнь осуждена на автоматизм; оно пробуждается, как только вновь возникает возможность выбора» (там же: 255), т. е. оно имеет объективно-субъективную природу. Таким образом, возникшее в процессе эволюции материальной природы сознание через присущий ему творческий порыв интуиции выходит на новую «творческую площадку» - пространство духа, на которой «кристаллизатором», блокировщиком порыва становится интеллект. Интуиция «выбрасывает» отдельное сознание в сферу творчества, интеллект, протестуя против этого отрыва от задач повседневности, возвращает его к земным делам.

Если концепция Бергсона описывает творчество как тотальный внешний механизм трансформации мира, то концепция системного аутопойезиса (в пер. с др. греч. - «самотворчество») У. Матураны и Н. Лумана предлагает механизм внутреннего творчества отдельно взятой системы. Живая природа, человек и его общество считаются аутопойетическими, т. е. такими системами, «которые в сети своих элементов порождают не только свои структуры, но и сами элементы, из которых они состоят» (Луман, 2011а: 68). Отсюда следует, что они обладают способностью к функциональному созданию новизны «по своей природе», создавая в том числе и сам эволюционный процесс: «Аутопойезис жизни являет собой единственное в своем роде биохимическое изобретение эволюции» (там же). Элементом в такой системе является некоторая операция, а не нечто вещественное; а в качестве структуры выступают «связи», «ожидания», «повторяемости» - ограничительные функции, ускоряющие действие, например, в обществе это коммуникации. Структура и весь механизм работы аутопойетических систем лишает их онтологического статуса: они как бы виртуальны.

Аутопойезис создает ситуацию автономности системы, ее относительной независимости от окружающего мира, в результате чего «возникают внутренние игровые пространства свободы» (там же: 69), что порождает внутрисистемную неопределенность будущего как на структурном, так и на операционном уровне, которая «потребовала» изобретения системой медиума «смысл» как способности, позволяющей прокладывать дорогу во временной последовательности событий. В такой трактовке смысл - не продукт сознания, а операциональная необходимость живого. 
Человек как исследователь таких систем может быть только внесистемным: «...Наблюдение всегда является некоторой операцией, которая должна проводиться посредством аутопойетической системы, и если понятие этой системы в этой ее функции обозначить как наблюдателя, то это влечет за собой следующее высказывание: наблюдатель есть исключенное третье своего наблюдения. В ходе наблюдения он не способен увидеть самого себя» (там же: 71-72), т. е. становится для себя «слепым пятном». «Система сама вынуждена осуществлять наблюдение своего наблюдения, описания своих описаний» (Луман, 2011b: 299). При таком представлении о процессах возникают два уровня проблем: интерсубъективности - наблюдатель должен согласовывать данные своих наблюдений с данными других наблюдателей, и многоуровневости наблюдения - наблюдения за наблюдателем.

В аутопойетических системах субъект исчезает, так как не нужно больше различение субъект-объектных отношений. По Луману, творчество человека как субъекта рождается из тех же предпосылок, что любая новизна в системе - из ее автономности и самовоспроизводства. Поскольку «всякое самоописание системы является конструкцией... система способна становиться неожиданностью для себя самой и получать из себя самой новое познание» (там же: 311).

Парадоксальность лумановского описания заключается в том, что тотальная автономность систем разного уровня «предназначалась быть предельно десубъективированным способом дескрипции» (Хоружий, 2016: 396). Об этом же ранее пишет Ю. Хабермас, утверждая, что Луман «совершает переход от субъекта к системе», и в этом переходе им руководит «желание подменить, не снижая уровня рефлексии, понятием системы, как оно разработано в кибернетическом и биологическом контексте, понятие субъекта сознания, развитое в философии от Декарта до Канта» (Хабермас, 2008: 376).

Другим результатом действия аутопойетических систем становится обоснование двузначно-логического мироописания, которое предстает как бы «в виде онтологии, а усилия по его обоснованию - в виде онтологической метафизики» (Луман, 2011b: 353). Нарастание количества и разнообразия социальных систем ведет к росту «софистичности описаний», что множит и вызывает к жизни противоположные описания. Рассматривая одно из таких двузначно-логических описаний - систему «целое/часть», Луман отмечает, что ее существование в сознании «указывает на более высокую инстанцию, на более охватывающее понятие природы или на акт творения... Но вместе с такими понятиями как эволющия, эмерджентность, дифференциация, самоорганизация пробивает себе дорогу совершенно иная 
Научные труды Московского гуманитарного университета

2019 № 1

установка мышления, исходящая из того, что без какого-то ни было верховного попечительства по отношению к целому могут возникать локальные, особым образом структурированные сущности (атомы, солнца, живые существа), которые затем задают условия приспособления и для других сущностей того же рода» (там же: 345-346).

В концепции жизни как аутопойетической системы, таким образом, исчезает понятие творчества как особого свойства сознания. Если творчество присуще в одинаковой мере всему живому, это значит, что оно тотально, т. е. неотличимо. Творчество духа становится таким же «операционным» «микротворчеством», как удвоение клетки. Концепция общества как системы коммуникаций Н. Лумана достоверно описывает и способствует пониманию того, что современное общество «работает» именно в этом горизонтальном поле «микротворчества». Отказ от вертикальной - классической и традиционной - картины мира, в которой творчество выводит индивидуальность за собственные рамки, поднимая по ступеням духа, вызывает у читателя ощущение отчаяния и безысходности, так как исчезают все значимые формы вертикального притяжения - Абсолют, Личность, Бог, а остаются только горизонтальные с приставкой пост- - пост-истина, пост-человек, пост-ценность и т. п. Концепция «аутопойезиса» систем отметает не только возможность особого статуса и ценности самотворчества индивида, но и личность как таковую. Она в научной форме олицетворяет добровольный отказ человека от духовного статуса в пользу будущего Мутанта и Киборга.

В качестве третьей модели творчества рассмотрим противоположную по духу лумановской классическую концепцию творчества в рамках русской религиозной философии. Н. А. Бердяев связывает творчество со смыслом и истиной через философию. «Философия есть творчество» и в то же время «философия всегда стремится постигнуть смысл мира <...> Основное предположение всякой подлинной философии - это предположение о существовании смысла и постижимости смысла» (Бердяев, 1994: 53, 54). Философия понимается здесь как творческий акт поиска смысла. Продолжая мысль Бердяева, что «философия ищет истину, а не истины» (там же: 52), можно сказать, что философия ищет не смыслы, а смысл, условием и средством чего является творчество. Философия открывает смысл жизни в специфике человека и обеспечивает связь понятия смысла с понятиями истины и творчества, т. е. три указанных понятия связаны, взаимоопределяемы и образуют абсолютное триединство: Творчество $\leftrightarrow$ Истина $\leftrightarrow$ Смысл, в котором существование одного без другого невозможно.

Рассматривая связь творчества и истины, Бердяев ставит вопрос: «Есть ли познание истины пассивность, послушность интеллекта или активность, 
творчество духа?» и отвечает на него так: «"Истина” пассивного интеллекта просто не существует, она есть лишь интеллектуальное выражение духовной подавленности и зависимости... Истина не есть дублирование, повторение бытия в познающем. Истина есть осмысление и освобождение бытия, она предполагает творческий акт познающего в бытии» (там же: 65).

Новое в творчестве может быть истиной, поскольку сам человек потенциально истинен и в его творчестве находит выражение полнота бытия. Творчество может становиться неистинным, «вытворением», когда оно не реализует истинную природу человека и не соответствует своей глубине. В этом случае лишенный спасающего щита истины человек духовно слабеет. Неистинность рельефно проступает в произведениях, которые намеренно (по заказу) или ненамеренно (по незнанию) искажают объективную реальность, фальсифицируя ее, или когда не хватает таланта (графоманство). Таким образом, соотношение двух частей из триединства само по себе не абсолютно: творчество может быть неистинным, а истина нетворческой. Но на пересечении творчества и истины рождается синтез, позволяющий сделать шаг в царство духа. Творчество - это аспект истины, отвечающий за ее новизну. Истина - это аспект творчества, отвечающий за его значимость. Творчество и истина оказываются в определенном смысле взаимосогласованными: чем больше творчества, тем больше истины. За пределами этой связи остаются безудержная фантазия и примитивная банальность.

Взаимодействие истины и смысла обсуждалось во все времена с момента зарождения философии. «Истина есть смысл и не может отрицать смысла. Отрицать смысл в мире значит отрицать истину» (Бердяев, 1994: 65). Существует связь, если так можно выразиться, горизонтов истины и смысла. Как и Бергсон, Бердяев расщепляет сознание, видя в пассивном интеллекте способность лицезреть лишь мертвую истину, тогда как живую истину видит только целостный дух, в котором живет и Логос, и «творческий свет, освобождающий и осмысливающий бытие» (там же: 66).

Связь между творчеством и смыслом не столь очевидна, как между творчеством и истиной. По происхождению слово «смысл» со-мысль, т. е. сопряжение, целостность мысли, единство чувственного и рационального, целомудрие, аналогично словам со-знание, со-весть, со-чувствие. Предлог «со» можно понимать двояко: как соединение мыслей индивида и как соединение мыслей всех людей. Понимание в первом значении приложимо к индивидуальному смыслу, понимание во втором значении - к общечеловеческому, а по нашей гипотезе, и вселенскому смыслу, смыслу эволюции.

Человек получает способность творчества, так как сам он есть результат творческого акта, будь то божественное творение (с позиции религии) или 
творчество эволюции (с позиции науки). Таким образом, с одной стороны, человек может создавать смыслы («Между сознанием и реальностью поистине зияет пропасть смысла» - см.: Гуссерль, 1994: 11), но с другой - сам он, как продукт творчества, его существование и способность к познанию, наделены смыслом, который может пониматься как смысл индивидуальной жизни, космической встроенности в бытие, смысл жизни во Вселенной и т. п.

Понятие смысла жизни, или, точнее, смыслоподобного существования, можно применить ко всем объектам Универсума, понимая принцип глобального эволюционизма как наращивание способности к созданию все более структурированной и «высокой» энергии. Если растения, потребляя энергию Солнца, создают биологическую энергию, животные - психическую, то человек - духовную. Способность к созданию своего типа энергии у растений и животных зависит от их положения на эволюционной лестнице, т. е. является врожденной. Человек, обладающий сознанием как внутренней свободой, может влиять на продукцию духовной энергии, усиливая ее, например, практиками СТ, или ослабляя безразличием к этой сфере своей жизни. Распространение этого принципа на духовную сферу придает новый ракурс триединству творчества, истины и смысла предположением, что смысл жизни человека, а также человечества и культуры, в трансформации телесного в духовное, поиск истины - процесс преобразования телесного в духовное, а творчество (в том числе и СТ) - способ данной трансформации (Горелов, 2013b: 180).

Творчество предстает как объективный процесс, происходящий в субъективности человека и опосредованный его свободой. Поэтому творчество себя, СТ, вписывается в контекст трансформации телесного в духовное как следующая стадия - переход духовного в телесное: в творчестве человек, будучи существом телесным, создает духовные модели - образы, символы, ценности, которые в результате последующей трансформации духовного в телесное (вхождение идеального образа в телесное) превращаются в объективные продукты деятельности человека - священные книги, философские трактаты, художественные сочинения, научные открытия, картины и т. д. При СТ на первом этапе как бы возникает замысел о себе и устремление к реализации, создается некий идеальный образ, который на втором этапе входит в реальную жизнь автора, изменяя его, т. е. продуктом, произведением становится сам человек как духовно-телесное существо. Если творчество есть создание и реализация культурных смыслов, то СТ есть создание и реализация смысла жизни.

Н. А. Бердяев относит возможность СТ к людям особого типа - святым. «Святому может быть присуща гениальность в самотворчестве, в превраще- 
нии себя в совершенную просиянную тварь, хотя никаких продуктов он может и не создавать» (Бердяев, 1993: 120). Но можно понимать СТ шире, предполагая, что это общечеловеческая способность открывать двери внутрь себя, т. е. возможность самостоятельного творения души. Тогда творчество и СТ выступают как две стороны единого процесса духовной эволюции человечества, осуществляющейся только в случае их постоянного взаимовлияния. Триединство «творчество - истина - смысл» для СТ имеет такое же значение, как и для творчества в широком смысле: путь внутрь себя может оказаться и не истинным, и не имеющим смысла. Диалектика их отношений вскрывает и «трагический конфликт творчества и личного совершенства... великий творец может быть гулякой праздным, может быть ничтожнейшим из детей ничтожных мира» (там же). Творчество дается «ни за что», просто так, и творец оправдан своим творчеством: «Мне есть, что спеть, представ перед Всевышним, мне есть, чем оправдаться перед Ним» (В. Высоцкий). Не известно, существует ли талант к СТ, ясно лишь, что во все времена - в античности, Средневековье и позже - были люди, которые ощущали себя призванными к этому, и это призвание исчезнет только в случае, если исчезнет человек.

Социальный аспект взаимодействия творчества, истины и смысла не пребывает неизменным: их взаимный конфликт снижается, когда общество встает на эволюционный путь развития, и, наоборот, усиливается, когда оно идет по инволюционному пути. Именно в этом случае возникает общественный запрос на революционеров духа, деятелей-творцов, не особенно заботящихся о материальных благах и успехе и способных расширить сознание для того, чтобы вырваться из круга обыденности, т. е. создать ситуацию, когда протест становится порывом и прорывом. Хотя духовность имеет глубоко личный характер, но «интенция ее социальная и даже космическая» (Бердяев, 1994: 446).

\section{Соотношение понятия СТ со сходными понятиями}

СТ также пересекается, но не совпадает полностью с самосовершенствованием. Если взять за основу сравнения корень этих слов, то СТ направляет человека с доверием отвориться духовному потоку, тогда как совершенствование ориентирует на движение, у которого есть вектор - вершина. Главная составляющая СТ - новизна, а самосовершенствования - нравственно-моральные установки. СТ предстает как вершина самосовершенствования, когда человек находится в пространстве полной свободы, устремляясь за границы собственной личности, конкретного социума и времени в сферу духа.

Кроме среза «телесное - духовное» в творчестве можно выделить ось «творение культуры - творение жизни». Творение культуры - общепри- 
Научные труды Московского гуманитарного университета

2019 № 1

нятое понятие, отражающее возможность создания новых образцов в различных отраслях культуры - искусстве, мифологии, философии, религии, науке. Идея «жизнетворения» впервые была высказана теоретиком русского символизма А. Белым, который рассматривал творчество как разыгрывающуюся драму, третий акт которой становится «творчеством индивидуальной жизни» творца (см. введение). Автор подчеркивает: чтобы «совершить подвиг перерождения мира, человек должен переродиться сам» (Тарновская, 2003: 385), причем, как отмечает русский писатель, это внутренняя революция, которая требует героических усилий и служения высшему началу.

Сходный мотив звучит в концепции «культуры себя» или «эстетики существования» М. Фуко. Человек конца XX в., ощущающий инволюционные тенденции мира и не поддерживаемый более ни традицией, ни разумом, должен стать «художником самого себя», т. е. найти внутренний источник для обретения автономии, без которой современность больше не может обойтись (Veyne, 1986: 939). Критикуя эстетизм позиции М. Фуко, П. Адо понимает под этой внутренней работой стремление к «преобразованию», «преображению», «самопревосхождению» (Адо, 2005: 286). На наш взгляд, противоречия тут нет, так как творчество себя включает все три состояния, отмеченные Адо как собственные этапы. Массовизация привела человечество к такому уровню гомогенизации, при котором творчество как необходимый механизм эволюции становится все менее возможным. Преобразование может начаться как бы с другой стороны, как протест каждого отдельного человека против массовизации и бездуховности общества потребления: СТ - это порыв в соответствии с синергетической динамикой развития.

СТ корреспондирует также к понятию «самоактуализация», возникшему в психологии XX в. Создатели теории самоактуализации А. Маслоу и К. Роджер увидели взаимообусловленность и взаимовлияние самоактуализации и творческой способности человека. А. Маслоу выделял несколько сторон самоактуализации: принятие себя, других и природы; разъединение, беспристрастность; желание уединения; автономность; сопротивление инкультурации; проблемо-центризм; демократическая структура характеpa (А. Маслоу, цит. по: Runco, 1999: 533). А. Маслоу, называвший самореализующихся людей «высшей ступенью человеческой зрелости», приходит к выводу, что на этой стадии «многие дихотомии, полярности и конфликты приходят к единству, преодолеваются или разрешаются. Самореализующиеся люди одновременно эгоистичны и бескорыстны, индивидуалисты и коллективисты, рациональны и нерациональны, связаны с другими людьми и отстранены от них, поклоняются одновременно Дионису и Аполлону» (Маслоу, 1997: 125). Эти качества и противоречия можно отнести и к харак- 
теристике творческой личности. К. Роджер пошел дальше, определив понятие «творчество» через самоактуализацию: «Творчество... человеческая способность актуализировать себя, стать более потенциальным» (Runco, 1999: 533). Он понимал творчество как изначальную потребность человека, которая должна быть удовлетворена, а самоактуализацию как внутреннюю настроенность творить - в рамках искусства, науки и, добавим, СТ. Не известно, что первично - творчество или самоактуализация, но одно ведет к другому и они взаимны. В теории двух выдающихся психологов-гуманистов творчество понимается как потенциальная способность любого человека, как повседневная способность создавать что-то для себя новое. Но эту способность к новизне необходимо пробуждать и чаще всего именно само-пробуждать, для чего и необходима самоактуализация. По Маслоу, можно говорить о «творчестве самоактуализации», которое как «излучение» пронизывает всю жизнь, невзирая ни на какие проблемы (Маслоу, 1997: 184). Согласимся с авторами концепции самоактуализации, что для любого творчества, в том числе и СТ, необходимо «включение» - заинтересованность, волевое усилие, осознание цели и т. д. Но эта зависимость не абсолютна: вероятно возможно СТ без самоактуализации и самоактуализация без СТ. Творчество и самоактуализация - многоликая конструкция, связи в которой не столь очевидны и единичны в силу уникальности каждой творческой личности.

В связи с вышесказанным можно выделить три функции СТ. Во-первых, любой вид творчества бессознательно оказывает влияние на творца, хочет он того или нет. Чтобы создать новое, надо измениться самому, стать обновленным. Вторая функция СТ заключается в сознательном воздействии творения культуры на человеческое бытие, что обнаруживается в древности в магии, а в наше время в науке (особенно в системе «наука - техника»). Хотя в этом случае речь идет не о внутреннем, а о внешнем бытии - социальном, политическом, экологическом и т. п. Третья функция представляет собой сознательное, как и в предыдущем случае, воздействие на самого себя, но как самоцель, а не как побочный продукт создания произведений культуры. В этом случае СТ становится прямой и главной целью. Такой путь характерен для мистики и религии. Святой не тот, кто хорошо говорит и пишет, а тот, кто поступает в соответствии со своими идеалами, ради утверждения которых он готов жертвовать собственной жизнью.

Пути СТ - самоактуализация, самопознание, самовыражение, выявление и развитие одаренности и способностей, самовоспитание деловых качеств - являются в то же время механизмами создания личности как единства сознания (интеллекта) и поведения (нравственности), проявля- 
Научные труды Московского гуманитарного университета

2019 № 1

ющегося в деятельности через чувства и волю. Поэтому контуры эволюционного развития СТ совпадают с контурами исторического становления индивидуальности и личности как общего потока духовной эволюции человечества. Сознание Человека разумного проходит несколько стадий от алогичного мышления, способствующего становлению коллективного бессознательного, через родовое коллективное сознание к индивидуальному сознанию, проявившемуся в осевое время. Многомерность осевого времени отразилась в параллельно происходящих процессах дифференциации - сознания (утверждение рациональности), культуры (появление философии как новой отрасли культуры), общества (разделение общественного труда, социальная дифференциация) - и интеграции - проявление индивидуальности и личности как материальной (телесной), социальной (по Дюркгейму, «орган общества») и духовной Единицы. Последующие наработки и достижения систем СТ ярче всего проявляются в духовных практиках, созданных в античности философией, а позже - мировыми религиями.

\section{Духовные упражнения как универсальная основа СТ}

Антропологический поворот, начатый европейской философией в конце XIX - начале XX в., к концу XX в. в работах ряда известных философов (М. Фуко, П. Адо и др.) обретает черты «обращения на себя», «практики себя». М. Фуко придает такого рода практикам универсальный смысл «революционного сознания»: «обращение человека на себя» возникало под разными видами в разные эпохи, не только в религии, но и в философии, морали, оно «впечатляюще и, можно сказать, драматично, внедряется в мышление, в практику, в опыт, в политическую жизнь, начиная с XIX века» (Фуко, 2007: 234). Как указывалось в предыдущем параграфе, опыт «обращения на себя» становится особенно востребованным в инволюционные эпохи, когда теряются смысл жизни, истина как цель, а творчество (в том числе и СТ) не востребовано. Тогда у людей, остро ощущающих время (как это было с самим Фуко), возникает желание изменить собственную жизнь (как пишет французский философ, «мыслить субъекта по-новому») через «техники себя», которые не сводятся «ни к техникам производства вещей, ни к техникам власти над людьми, ни к символическим техникам» (Ф. Гро, цит. по: Хоружий, 2010: 495). Само понятие духовности Фуко определяет через эти «поиски, практику и опыт, посредством которых субъект производит в себе самом изменения, необходимые для того, чтобы получить доступ к истине... это могут быть практики очищения, аскеза, отречение, обращение, изменение образа жизни» (Фуко, 2007: 27). Он усматривает широкий контекст развития духовных «техник себя» в античности, где они проходят как бы три ста- 
дии: самую общую - «заботы о себе», история которой охватывает «тысячу лет с V в. до Р. X. по V в. после, которая вела от первых форм философской деятельности, какими мы их видим у греков, к первым формам христианской аскетики» (там же: 24), далее «практики себя», к которой обращались в той или иной мере все философские школы после Сократа, и «культуры себя», включающей кинические, эпикурейские и стоические практики как вершину данного пути в эллинистическую эпоху (I-II вв.).

Широкая трактовка концепции «практики себя» имеет в виду «преобразование субъекта с целью сообразования его с истиной», которое «придает завершенность... позволяет ему сбыться» (там же: 28, 29). «Истина не дается субъекту простым актом познания <...> она дается только ценой введения в игру самого существования субъекта» (там же: 28). Мы находим в его концепции те же атрибуты, что и в нашей идее CT, - глубинное преобразование, поиск истины, но смысл действий другой: «Цель практики себя - я сам <...> нет ни иной цели, ни иного предела, чем прийти к себе самому, “установиться в себе самом" и там остаться»» (там же: 146-147, 538). Даже в зените своего развития, в эллинистической «культуре себя», античные адепты ограничивались «этим миром», земным миром человеческого существования. Поэтому речь в этих практиках идет не о выходе за пределы самости в «мир дольний», не о размыкании (навстречу новым энергиям), а скорее о замыкании на самого себя (Хоружий, 2010: 502). Ни самое эллинистическое мировоззрение, ни его современный интерпретатор М. Фуко не могут решить «представляет ли собой «себя» (le soi) что-то такое, к чему возвращаются, потому что оно уже имелось заранее, или это цель, которую надо перед собой поставить и которой можно в конце концов достичь» (Фуко, 2007: 240). Этим высказыванием Фуко обнажает возможную двойственную цель практики себя: либо возвращение к себе (в глубинного себя) - ауто-субъективация, либо претворение себя, «выход из себя», разрыв с прежним, - транс-субъективация. По мнению Фуко, третьего не дано.

Важнейшими концептами практики себя стали установки «обращения-на-себя», «участия Другого», «всеобщности - исключительности» (Хоружий, 2010: 508). Установка «поворота на себя» переводила жизнь человека в пространство наибольшей свободы - свободного самоосуществления, которое оставалось «незатронутым регламентирующей деятельностью как полиса и закона, так и религии» (Фуко, 2007: 485). Ее проводником стала вновь возникшая отрасль культуры - философия. Главной особенностью античной философии можно считать отсутствие дистанции между теорией и практикой: философы изначально считали своим призванием не столько познание мира, сколько изменение человека. Современная трактовка 
отправной точки «начала пути» очень точно передает установку античности: «Надо отвернуться от всего того, что отворачивает нас от нас самих, и повернуться к себе. Один и тот же внушительный образ - образ обращения на себя маячит за всеми этими представлениями <...> надо в самом себе найти точку и оставаться неподвижным по отношению к ней» (там же: 233). Фуко приводит несколько видов «архаичных техник себя», которые существовали в религиозных практиках и способствовали «обращению-на-себя»: «обряды очищения», «техники концентрации души», «техники отрешения» (отшельничество), «практики выносливости» (там же: 62-63).

Обращение на себя не ведет к духовному аутизму в том случае, если присутствует транс-индивидуальное измерение, некий Другой, который предоставляет несколько вариантов духовных «услуг». Он и «образец поведения, пример, предлагаемый более молодому и необходимый для воспитания»; и осуществляет особый тип учительства - «сократовский диалог: создание трудных ситуаций и поиски выхода из них» (там же: 148); и духовный лекарь, так как человек неспособен «быть собственным лекарем... при исцелении от страстей и ошибок» (там же: 429); в общем этот Другой - «специалист по переустройству индивида, по формированию из него субъекта. Он опосредует становление индивида в качестве субъекта» (там же: 150). Возникает коммуникация Учитель-Ученик, которой Фуко придает смысл центрального элемента практики - «поэтапной субъективации истинной речи» (там же: 394) в результате парресии («полная откровенность, открытость, свобода речи, слова» (там же: 395)), создающей уровень глубинного общения.

В концепции «практики себя» присутствует внутреннее противоречие: с одной стороны, цель «стать истинным собой» должна стать устремлением каждого человека, его предназначением, но, с другой, история показывает, что «лишь очень немногие на самом деле способны заниматься собой. Не хватает духа, силы, выдержки; неспособность довести дело до конца - таков в действительности удел большинства» (там же: 138). В эллинистической культуре, где практики себя были широко распространены и популярны, существовало как бы два полюса подхода к ним. «...Один более простонародный, более религиозный, более культовый, теоретически более примитивный... $\mathrm{a}$ на противоположном полюсе... практики себя, более индивидуальные, более личностные, облагороженные, чаще встречающиеся в наиболее обеспеченных слоях и отчасти опирающиеся на дружеские связи» (там же: 135). Речь идет о полярности духовных практик «заботы о себе» и «культуры себя», представленных в одном обществе - в Древнем Риме I-II вв.

Очевидно, говорить о реальном выборе практики себя можно только в ситуации именно этого второго полюса, когда осуществляется личный 
выбор (часто вопреки мнению окружающих). Такая «практика себя оказывается принципиально отличной от всех практик обычного существования человека... радикально альтернативной самому способу эмпирического существования» (Хоружий, 2010: 509-510), именно поэтому этот способ жизни становится уделом избранных. То, что Фуко называет «игрой всеобщности призыва.... и исключительности спасения» (Фуко, 2007: 140), существует во всех духовных практиках, которые обращены к каждому, но реально в них вовлекаются лишь единицы, причем в этих людях, в силу избранности, легко пробуждается гордыня, что проглядывает в текстах римских «аристократов духа» Сенеки, Марка Аврелия (но не у раба Эпиктета!) и обнажает тупиковость «практик ради себя». По своей сути СТ не может быть «практикой только себя», потому что ему нужны «разомкнутость» и внешние энергии для самоосуществления через прикосновение к бытию (Богу). Вопреки мнению Фуко, духовные практики прошлого не могут быть перенесены в настоящее уже в силу того, что многое изменилось - сам человек, социум, среда, в том числе и природная. Время требует новых духовных практик, которые возникнут в результате духовного синтеза того, что накоплено, и нового порыва СТ.

Тема «искусства жизни» объединяет концепцию М. Фуко с точкой зрения другого его современника - П. Адо, который признавал за античной философией установку искусства жить, особой формы жизни. По мнению Адо, все известные философские системы античности уделяли внимание методологии воздействия на человека, которые можно назвать «духовными упражнениями». «...Эти упражнения... соответствуют преобразованию видения мира и метаморфозе личности. Слово «духовный» действительно позволяет понять, что эти упражнения являются творчеством не только мысли, но всей психики индивида... благодаря им индивид возвышается к жизни объективного Духа» (Адо, 2005: 22; курсив наш. - А. Г., Т. Г.). П. Адо называет четыре главных типа духовных упражнений: 1) «научиться жить»; 2) «научиться вести диалог»; 3) «научиться чтению»; 4) «научиться умирать».

Установка «научиться жить» в широком смысле предполагает преуспеяние «в искусстве жизни, в конкретной установке, в сообразном стиле жизни, затрагивающем все существование» (Адо, 2005: 23-24). Она означает переход от неподлинного состояния жизни, которое подчиняется внутреннему голосу страстей и страхов и разъедается внешними обстоятельствами забот, бедности и т. п., к подлинной жизни, основанной на сознании и внутренней свободе. Беспорядочные страсти и необоснованные страхи, суета заботы - главные помехи на пути саморазвития. Задача философии состоит в создании такой экзистенциальной методологии, которая действовала 
Научные труды Московского гуманитарного университета

2019 № 1

бы по принципу самолечения, врачевания души без посторонней помощи. Каждая философская система античности по существу и занималась созданием философской «медицины» души, способствуя смене видения и бытия человека. Главная проблема, которая возникает в этом случае: как выявить то благо, которое человек в состоянии добыть, и как отличить то зло, которое можно избежать.

Вторая - «научиться вести диалог» и третья - «научиться чтению» группы духовных упражнений, по классификации Адо, соответствуют концепции «участия Другого» М. Фуко. Представляется, что их лучше объединить в одну группу - «научиться общению с Другим», имея в виду, что диалог - это непосредственное общение, а чтение - это опосредованное, через текст, общение с той же целью - найти истину. Еще одна группа духовных упражнений «научиться умирать» предлагает при выборе между Жизнью и Идеей выбрать последнюю. Это сознательная процедура освобождения от телесных тягот и страстей ради обретения независимости мышления, его перехода к универсальности и объективности.

П. Адо находит очень точное определение античным духовным практикам - «научение», поскольку они «шли от головы» и преподавались в философских школах. Но в этом «научении» присутствует момент, который характеризует именно духовную практику - стремление к разрыву с повседневным образом жизни, пренебрежение общепринятым жизнеустройством, привычными взглядами и поведением. Изначальный мотив философа, который собственно и является творчеством, - создать свое $p a-$ циональное представление о состоянии совершенства и соответствующие духовные практики, упражнения разума, настраивающие индивидуальную жизнь на духовное продвижение к идеалу мудрости, к проявлению в себе как субъекте некоего Всеобщего. Духовные практики, которые при этом создавались, были СТ их авторов, но поскольку у каждого из них находилось много последователей, эти упражнения несли в себе ядро всеобщего, как бы общий план структуры и возможностей СТ в рамках философии. Античные духовные системы обладали, казалось бы, всеми атрибутами триединства «творчество-истина-смысл»: творческим накалом из-за высокой конкурентности философских школ, устремлением к истине через разные типы доктрин, но предлагаемого ими смысла — «я сам», «обращения-на-себя» явно не хватило для всеобъемлющего духовного синтеза.

Необходимость такого синтеза и возможность его зарождения возникли позже, в христианстве, что осознала русская философия с XIX в. Современную потребность синтеза выражает, в частности, синергийная антропология, принявшая эстафету от византийского православия и русской 
философии всеединства. «Отправляясь от аутентичной византийской концепции синергии... синергийная антропология совершает ряд последовательных обобщений, расширяя ее до некоторой универсальной парадигмы конституции человека - «парадигмы антропологического размыкания»» (Хоружий, 2016: 21).

Понятие «synergia» (соработничество, согласованное действие), отражающее позднеантичное устремление действовать в модусе слияния, содействия, в восточном христианстве выражает встречу и соработничество Божественной (несотворенной) и человеческой (сотворенной) энергий, которые достигаются в результате особой духовной практики - исихазма (от греч. «hesychia» - уединение, покой). Исихастская практика представляет собой восхождение по «духовной лестнице» - Лествице, первой ступенью которой является обращение и покаяние (уход от мира), а последней «обожение», когда происходит «целостное и фундаментальное преобразование человеческого существа, производимое Божественной энергией, которая действует в человеке, проявляясь явно и зримо в силу синергии» (там же: 26). Синергийность процесса нарастает в результате соединения двух активностей - внимания и молитвы (непрестанная молитва), которые на более высоких ступенях, с одной стороны, делают «более и более явственным действие некоторой «внешней энергии», т. е. энергии, которая воспринимается человеком как не принадлежащая ему и приходящая извне» (там же: 25), а, с другой, нарастает спонтанность состояния («самодвижная молитва», «умные чувства»), что делает весь процесс, похожим на самоорганизацию в неравновесном состоянии: чем выше организация, тем сильнее спонтанность. Критикуя христианскую практику аскезы, Фуко высказывался в том смысле, что ее целью является «отказ от себя»; что она «учреждает какой-то порядок жертвоприношений, обязательных отказов от чего-то в себе и своей жизни»; что она «основана на принципе подчинения индивида закону» (Фуко, 2007: 359). Для атеистического сознания французского философа «отказ от ветхого себя» воспринимается не как первый шаг на пути к себе новому, а как саморазрушение под давлением христианского закона и морали. Для христианского же мироощущения оставляемое без проработки ядро «себя», полное плотских желаний и страстей, становится духовным тупиком и рабством у тела. Дилемма ауто-субъективации как возвращения к «истинному себе» и транс-субъективации как «выхода из себя», разрыва с прежним, поставленная Фуко, в рамках синергизма получает простое решение: «обожение» - это одновременно и обретение истинного себя.

Движение по Лествице - это также конструирование человеческой личности, открытие истины и смысла ее существования: «В меру единства 
моего со Христом я должен понимать себя как личность. И в этом открывается мне истинный смысл моего личного бытия: ...я истинно - «соработник» Христа» (Карсавин, 1994: 184). Синергия ответственна не только за размыкание навстречу божественной энергии, но также за «онтологическое размыкание навстречу личному бытию» (Хоружий, 2016: 27). По С. С. Хоружему, «размыкание» - это широко распространенная духовная практика, в которой «существует дихотомия: онтологический горизонт... может представлять личное бытие (как в случае христианства и ислама), либо бытие безличное (как во всех религиях Востока)» (там же: 30). Продвижение к «безличному телосу», будь то Единое, Небо, Великая Пустота, происходит за счет внутреннего выравнивания структур и энергий, ведущего к «изгнанию всех эмоций и охлаждению внутренней реальности <...> своего рода само-деконструкция человека» (там же: 32, 31).

Гораздо более глубокая деконструкция наметилась в связи споявлением в начале XXI в. виртуальных практик, которые означают уход из актуальной среды, чем наносится ущерб личному общению как внешне (сокращается время), так и внутренне (актуальное общение становится более поверхностным, приближаясь к виртуальному). Эту опасность общего ослабления, а возможно и разрушения связей с реальностью, следует считать главной опасностью с точки зрения СТ. Перенос практик самотрансформации в виртуальную среду обольщает человека большими возможностями: слабый может представить себя сильным, бесталанный наградить талантом, но на самом деле является глубочайшей подменой и потерей основ духовного самоизменения. По мнению С. С. Хоружего, общий тренд антропотрансформаций от Онтологического Человека («разомкнутого» божественной энергии) через Онтического Человека («разомкнутого» энергии бессознательного) к Виртуальному Человеку означает Уход (самоустранение) Человека как вида из современного «общества риска» и его замену Постчеловеком (Киборгом или Мутантом) (Хоружий, 2010, 2016). Что же должно произойти, чтобы человечество свернуло с этого гибельного пути?! «Возвращение к себе» во все времена было акцией духовного протеста, а в наше время становится шагом в сторону с «магистральной дороги в никуда».

\section{Заключение}

Духовные практики, к которым относится СТ, представляют собой холистические «практики себя» (в терминах Фуко) со строгим методом и ступенчатой структурой, начинающиеся как выбор жизненного пути, осознаваемый или отчасти бессознательный. На первой ступени выбор проявляется как протест против повседневности, обстоятельств и условий жиз- 
ни, в которой на всех социальных расстояниях (семья, группа, общество) господствует потребление, конкуренция и борьба за власть; в терминах М. Хайдеггера, это «поворот-к-себе», внутренний выбор в пользу «вопрошания бытия» как способа осуществления человека бытийственного (Dasein) и отказа от безличного, стертого сознания массового человека (das Man). На следующей ступени предстоит выбор стратегии «обращения». Как показывает анализ Фуко, «обращение-на-себя» в античных «практиках себя» способствует культивации «неприкасаемого» глубинного ядра «себя». «Обращение-к-Единому» в восточной парадигме духовных практик ведет к растворению персоналистических структур, т. е. фактически не имеет отношения к СТ. «Обращение-к-Богу» в христианстве и исламе предполагает предельную полноту самораскрытия («размыкание себя» божественной энергии) и одновременно персоналистическое строительство. Три указанных духовных комплекса создавались в течение столетий, и каждый из них к настоящему времени предстает как «органон духовного опыта», в котором представлен «полный свод правил его подготовки, организации и интерпретации» (Хоружий, 2016: 248). Они реализуют известные альтернативы актуального саморазвития, составляют стержень и границы личных траекторий жизненного пути: человек ступает на дорогу и она ведет его сама. Так что выбор - «получение наибольшего удовольствия» (М. Фуко), «демонтирование» личности (восточные практики) или достижение состояния приобщенности и благодати (христианство) - это изначальный выбор, который задает смысл всей программе СТ.

Следующая ступень предполагает овладение доктриной и практикой в рамках избранного пути. В традиционной культуре существовали две версии: одна для большинства, другая для избранного круга интеллектуалов. В античности широкие массы практиковали языческие культы местных богов, причем некоторые из них были достаточно сложны и требовали глубокой аскезы (например, культ Исиды, на всех адептов которого «налагались строгие ограничения в еде, в половой жизни, им вменялись в обязанность исповедание грехов, покаяние и т. п.» (Фуко, 2007: 133)), а античные интеллектуалы создали новую отрасль культуры - философию, включавшую широкий спектр доктрин и связанных с ними систем самоконтроля, заложивших основы личностного подхода к СТ. Средневековое христианство и ислам также создали массовые институциональные религиозные формы, причем если в западном католичестве преобладала всесторонняя доктрина (например, «Сумма теологии» Ф. Аквинского), то в восточном православии больше была развита духовная практика, в которой выкристаллизовались «практики для избранных» - старчество и юродство. В исламе аналогич- 
ное различение привело к ортодоксальному исламу (шиизм и суннизм) и суфизму (мистический ислам), в буддизме выделился дзэн. Современное глобальное общество отличается от предшествующих эпох тем, что больше нет традиционных ниш для массового «выхода из повседневности», потому что он больше не востребован породившими его культурами, есть только личный выбор СТ, который в социальном ракурсе предстает как исключение, жизненный эксперимент над собой. Широкое распространение восточных практик (дзэн-буддизма и йоги) на Западе (особенно в США), чему способствовали их простота и пластичность, возникло из потребности в вере человека, «утерявшего Бога», но не потерявшего желания верить, что и делает «религию без бога» подходящим психотренингом западному индивидуализму. Глобальные религиозно-культурные заимствования свидетельствуют о тоске по самореализации и поиске нового проекта духовного созидания. Творчество присуще природе, но только сознание человека задает ему направление - поиск истины и цель - смысл жизни. История программ СТ показывает, что в основу будущего проекта должна быть заложена реализация по-новому осмысленного Личностью духовного триединства «Творчество-Истина-Смысл».

\section{СПИСОК ЛИТЕРАТУРЫ}

Адо, П. (2005) Духовные упражнения и античная философия / пер. с франц. при участии В. А. Воробьева. М. ; СПб. : Изд-во «Степной ветер» ; ИД «Коло». $448 \mathrm{c}$.

Белый, А. (1990) Революция и культура // Александр Блок, Андрей Белый: диалог поэтов о России и революции / сост., вступ. ст., коммент. М. Ф. Пьяных. М. : Высшая школа. 687 с. С. 471-489.

Бергсон, А. (2001) Творческая эволюция / пер. с фр. В. Флеровой; вступ. ст. И. Блауберг. М. : ТЕРРА-Книжный клуб ; КАНОН-пресс-Ц. 384 с.

Бердяев, Н. А. (1923) Философия неравенства. Берлин : Обелиск. 128 с.

Бердяев, Н. А. (1993) О назначении человека. М. : Республика. 383 с.

Бердяев, Н. А. (1994) Смысл творчества // Бердяев Н. А. Философия творчества, культуры и искусства: в 2 т. / вст. ст, сост., примеч. Р. А. Гальцева. М. : Искусство ; ИЧП «Лига». Т. 1.541 с.

Горелов, А. А. (2013а) Лекарство от бессмысленности. Духовность. Целостность. Индивидуальность. М. : Летний сад. 600 с.

Горелов, А. А. (2013b) Творчество, истина и смысл // Эпистемология креативности / отв. ред. Е. Н. Князева. М .: «Канон+»; РООИ «Реабилитация». 520 c. C. $149-180$. 
Гуссерль, Э. (1994) Идеи к чистой феноменологии и феноменологической философии / пер. с нем. А. В. Михайлова. М. : Лабиринт. 489 с.

Карсавин, Л. П. (1994) О началах // Карсавин Л. П. Сочинения / подг. текста и послеслов. А. К. Клементьева. СПб. : УМСА-пресс, Scriptorium. Т. 6. $375 \mathrm{c}$.

Луман, Н. (2011а) Общество общества. Кн. 1. Общество как социальная система / пер. с нем. А. Антоновский. М. : Логос. 640 с. С. 9-202.

Луман, Н. (2011b) Общество общества. Кн. 5. Самоописания / пер. с нем. А. Антоновский, Б. Скуратов, К. Тимофеева. М. : Логос. 640 с. С. 289-588.

Маслоу, А. (1997) Психология бытия / пер. О. О. Чистяков. М. : Рефл-бук ; Ваклер. 304 с.

Петров, В. В. (2018) Революция 1917 года в современной ей литературно-философской апокалиптике // Революция, эволюция и диалог культур. Доклады к 100-летию русской революции на Всемирном дне философии в Институте философии РАН 14 и 16 ноября 2017. / отв. ред. А. В. Черняев. М. : Гнозис. 624 с. С. 69-94.

Тарновская, Е. О. (2003) Владимир Соловьев и концепция «жизнетворчества» А. Белого // Серия «Sуmposium». Минувшее и преходящее в жизни и творчестве В. С. Соловьева. Вып. 32 : Материалы Межд. конференции, 14-15 февраля 2003. СПб. : Санкт-Петербургское филос. общество. 427 с. С. 384-388.

Франк, С. Л. (1990) Непостижимое. Онтологическое введение в философию религии // Франк, С. Л. Сочинения. М. : Правда. 608 с. С. 183-559.

Фуко, М. (2007) Герменевтика субъекта: Курс, прочитанный в Коллеж де Франс в 1981-1982 учебном году / пер. с фр. А. Г. Погоняйло. СПб. : Наука. $677 \mathrm{c}$.

Хабермас, Ю. (2008) Философский дискурс о модерне. Двенадцать лекций / пер. с нем. 2 изд., испр. М. : Весь мир. 416 с.

Хайдеггер, М. (1997) Бытие и время. М. : Ad Marginem. 452 c.

Хоружий, С. С. (2010) Фонарь Диогена. Критическая ретроспектива европейской антропологии. М. : Институт философии, теологии и истории св. Фомы. 688 с.

Хоружий, С. С. (2016) Социум и синергия: колонизация интерфейса. Казань : Казанский инновационный университет им. В. Г. Тимирязева (ИЭУП). 452 с.

Шелер, М. (1988) Положение человека в Космосе // Проблема человека в западной философии: Переводы / сост. и послеслов. П. С. Гуревича; общ. ред. Ю. Н. Попова. М. : Прогресс. 552 с. С. 31-95.

Encyclopedia of Creativity (1999) / Ed. by V. F. Runco, S. R. Pritzker. N.-Y. : Academic Press. V. 2. 810 p. 
Runco, M. A. (1999) Self-Actualization // Encyclopedia of Creativity / Ed. by V. F. Runco, S. R. Pritzker. N.-Y. : Academic Press. V. 2. 810 p. P. 533-536.

Veyne, P. (1986) Le dernier Foucault et sa morale // Critique. № 471-472. P. 920-932.

Дата поступления: 12.10.2018 2.

Горелов Анатолий Алексеевич — доктор философских наук, ведущий научный сотрудник Института философии РАН. Адрес: 119842, Россия, г. Москва, ул. Гончарная, д. 12. Тел.: +7 (495) 697-91-28. Эл. адрес: evolepis@iph.ras.ru

Горелова Татьяна Анатольевна - доктор философских наук, профессор кафедры философии, культурологии и политологии Московского гуманитарного университета. Адрес: 111395, Россия, г. Москва, ул. Юности, д. 5. Тел.: +7 (499) 374-55-11. Эл. адрес: fylosofy@mosgu.ru

Gorelov Anatoly Alekseevich, Doctor of Philosophy, Chief Research Fellow, Institute of Philosophy, Russian Academy of Sciences. Postal address: 12 Goncharnaya St., 119842 Moscow, Russian Federation. Tel.: +7 (495) 697-91-28. E-mail: evolepis@iph.ras.ru

Gorelova Tatyana Anatolievna, Doctor of Philosophy, Professor, Department of Philosophy, Culturology and Politology, Moscow University for the Humanities. Postal address: 5 Yunosti St., 111395 Moscow, Russian Federation. Tel.: +7 (499) 374-55-11. E-mail: fylosofy@mosgu.ru

\section{Для цитирования:}

Горелов А. А., Горелова Т. А. Самотворчество как протестный потенциал духовной культуры [Электронный ресурс] // Научные труды Московского гуманитарного университета. 2019. № 1. URL: http://journals.mosgu.ru/trudy/article/view/943 (дата обращения: дд.мм.гг.). DOI: 10.17805/trudy.2019.1.14 